TABLE 1 Summary of all sightings of northern bald ibis Geronticus eremita by the Migres Foundation.

\begin{tabular}{|c|c|c|c|c|c|c|}
\hline Date & Time & Number & Direction & Crossing & Observer & Observation point \\
\hline 29 Sep. 2010 & 11.08 & 15 & $\mathrm{~N}-\mathrm{N}$ & & & Cazalla \\
\hline 28 July 2014 & 12.36 & 1 & $\mathrm{~N}-\mathrm{S}$ & Yes & Alejandro Onrubia & Cazalla \\
\hline 30 July 2016 & 10.09 & 7 & $\mathrm{~N}-\mathrm{S}$ & & Andrés de la Cruz & Cazalla \\
\hline 31 July 2016 & 13.54 & 6 & $\mathrm{~S}-\mathrm{N}$ & & Andrés de la Cruz & Cazalla \\
\hline 20 Aug. 2016 & 13.48 & 21 & W-E & & Carlos Torralvo & Cazalla \\
\hline 9 Sep. 2016 & 10.15 & 19 & NW-SE & Yes & Alberto Lobo & Cazalla \\
\hline 9 Sep. 2016 & 11.06 & 22 & W-E & & Erin Arnold & Algarrobo \\
\hline 23 Sep. 2016 & 11.29 & 11 & NW-S & Yes & Carlos Torralvo & Cazalla \\
\hline 24 Sep. 2016 & 09.18 & 8 & S-NW & & Alejandro Onrubia & Cazalla \\
\hline 10 Oct. 2016 & 12.27 & 1 & W-E & & Carlos Torralvo & Cazalla \\
\hline 2 Nov. $2016^{*}$ & 10.10 & 6 & NE-SW & Yes & Alejandro Onrubia & Tarifa \\
\hline 8 Aug. 2017 & 09.42 & 1 & NW-SE & & Alejandro Onrubia & Cazalla \\
\hline 8 Aug. 2017 & 10.12 & 1 & E-W & & Alejandro Onrubia & Cazalla \\
\hline 10 Nov. 2017 & 10.00 & 5 & $\mathrm{~N}-\mathrm{S}$ & Yes & Alejandro Onrubia & Tarifa \\
\hline 11 Nov. 2017 & 08.10 & 3 & $\mathrm{~N}-\mathrm{S}$ & Yes & Alejandro Onrubia & Tarifa \\
\hline
\end{tabular}

*The same birds were seen arriving in Tangiers by Muñoz \& Ramirez (2017).

Proyecto Eremita on that day. None of these subsequently returned to the project. All Proyecto Eremita birds are fitted with unique coded darvic rings. Only the observation in 2014 was confirmed to be an adult. Most birds making the crossing seem likely to be hand-reared juveniles. The birds that crossed towards Morocco in early November 2017 did not, however, coincide with a disappearance from Proyecto Eremita.

In 2016 a total of 101 northern bald ibises were observed crossing or part-crossing the Gibraltar Straits in nine separate observations. Many of these sightings undoubtedly involved the same birds passing, but 36 birds (observations on three separate dates) were observed crossing to the south. It is possible that at least some of the birds returned to Spain undetected during this period. A minimum of 19 birds were seen crossing to Morocco on 9 September 2016, and it is possible that the six observed on 2 November were surviving birds from that larger group, attempting the crossing back to Spain (having already set off north from Morocco).

The Proyecto Eremita reintroduced population has now successfully bred 90 free-flying ibises, and 25 pairs bred in the wild in 2017 with no significant intervention. These birds remain largely sedentary (regularly moving up to $45 \mathrm{~km}$ but rarely more than this). Austrian work to establish free-flying ibises reported multiple long-distance movements (several hundred $\mathrm{km}$ ) of mainly juveniles, and only by enclosing the birds each autumn did they remain in the area (Fritz et al., 2017, International Book Yearbook, 51, 107-123), and enclosure in autumn is also used at Proyecto Eremita. Whether this population will develop a regular dispersion or migration pattern to the south remains unclear, and the continued monitoring and marking of the free-flying Proyecto Eremita juveniles is important, to differentiate between these and the possibility of sightings involving the slowly increasing, fully wild Moroccan birds dispersing to the north.

We thanks the full Migres Foundation team, and specifically Andrés de la Cruz, Carlos Torralvo, Erin Arnold and Alberto Lobo for their observations.

CHRistopher G. R. Bowden Royal Society for the Protection of Birds, Sandy, Bedfordshire, UK.

E-mailchris.bowden@rspb.org.uk

Jorge Fernández ORUETA SEO/BirdLife, Madrid, Spain

José Manuel López VÁzQuez Consejería de Medio Ambiente y Ordenación del Territorio, Junta de Andalucía, Cádiz, Spain

Alejandro Onrubia Migres Foundation, Tarifa, Spain

Miguel Angel Quevedo Zoobotánico Jerez, Cádiz, Spain

\section{A global effort to improve species monitoring for conservation}

We know biodiversity is in decline but our ability to monitor the status of species, and threats, and to assess the outcomes and impacts of conservation projects, is limited by a lack of adequate data. Obstacles to data collection, access and use are numerous and include weak indicators and monitoring plans, inadequate resources and capacity, lack of appropriate tools and limited sharing of data (Stephenson et al., 2017, Biological Conservation, 213, 335-340). As a result, there are large biases and gaps in our knowledge (e.g. there are more data on vertebrates than invertebrates, and more data on European species than African species). Although satellite- 
based remote sensing offers some opportunities to track biodiversity, our knowledge of species will only advance if we develop capacity for in situ monitoring, especially in biodiversity-rich countries (Stephenson et al., 2017, Frontiers in Ecology and the Environment, 15, 124-125).

In 2016 the IUCN Species Survival Commission (SSC) formed the Species Monitoring Specialist Group (https:// www.speciesmonitoring.org) to address the ongoing challenges with biodiversity monitoring. The Group's mission is to enhance biodiversity conservation by improving the availability and use of data on species populations, their habitats, and threats. Our objectives focus on improving the accessibility of appropriate tools and methods to fill data gaps, building capacity for monitoring, enhancing data collection and use (especially for neglected taxa), and ensuring databases are inter-linked and meet users' needs. The Group's unique aim is to enhance the volume and quality of data feeding into the IUCN Red List of Threatened Species. Group members-drawn from a variety of disciplines with experience as data collectors and users across regions and taxa-work in close partnership with key data stakeholders, including relevant organizations (e.g. UN Environment World Conservation Monitoring Centre, UNEP-WCMC), networks (e.g. Group on Earth Observations Biodiversity Observation Network), partnerships (e.g. the new Specialist Group is a Data User Partner of the Biodiversity Indicators Partnership) and alliances (e.g. the Eye on Earth Alliance), as well as government agencies, NGOs, local communities, academic institutions and the private sector.

One of the Specialist Group's challenges is to prioritize its efforts, and early work is focusing on identifying data and capacity gaps. In November 2017 that work began with the start of a project funded by the Cambridge Conservation Initiative Collaborative Fund (http://www.cambridgeconserva tion.org/collaboration/global-audit-biodiversity-monitoring). The Specialist Group, Birdlife International, RSPB, the University of Cambridge, UNEP-WCMC and the Zoological Society of London are working with their network of partner organizations to conduct the first global audit of biodiversity monitoring. This will include identifying the main geographical and taxonomic gaps in biodiversity monitoring, compiling an inventory of schemes and the methods they use, and linking data collectors with data users. In parallel, the Group is reviewing data needs across the SSC taxonomic specialist groups by surveying members, and reviewing lessons learned on species monitoring from large project portfolios, such as the IUCN Save Our Species Programme. The Group is also planning more in-depth analyses of global databases, building on recent studies (e.g. McRae et al., 2017, PloS One, 12, e0169156). Complementary work underway includes the identification of sites in Africa, Asia and Latin America where partner agencies will help develop and test standardized monitoring methods and protocols to enhance collection of data on poorly-known species, including the application of the proposed IUCN Green List of Species (Akçakaya et al., 2018, Conservation Biology, https://doi.org/10.1111/cobi.13112). The Group's chair is also working with the IUCN Business and Biodiversity Programme to explore options for biodiversity monitoring frameworks for the private sector, building on collaborative work started with the energy company Enel (https://www. iucn.org/news/business-and-biodiversity/201710/iucn-andglobal-energy-company-enel-develop-biodiversity-bestpractices).

The initiation of the Species Monitoring Specialist Group will ensure that by 2019 IUCN and its commissions, members and partners, and the broader academic and conservation communities, will have a clearer idea of where biodiversity data are most needed. The aim then will be to focus the Group's attention and expertise on building capacities to fill identified gaps. Ultimately this will lead to an improvement in conservation planning, the enhanced monitoring of project impacts and outcomes, and improved results-based reporting by governments on global environmental goals such as the Aichi Targets and the Sustainable Development Goals.

P.J. STEPHENSON Chair, IUCN Species Survival Commission Species Monitoring Specialist Group, c/o Ecosystem Management Group, Department of Environmental Systems Science, ETH Zürich, Zürich, Switzerland.

E-mail stephensonpj@gmail.com

\section{Restoring nature with evidence}

A new website, http://www.restorationevidence.org, is gathering and summarizing scientific evidence for the effectiveness of interventions to restore degraded habitats. A subset of https://www.conservationevidence.com dealing only with restoration, the site is a collaboration between the Endangered Landscapes Programme and Conservation Evidence, making evidence freely available to all. This will help ensure funds are spent on interventions that are most likely to be effective in achieving a desired outcome, from restoring upland grazing pastures into blanket bog to converting ranches into tropical forests.

So far, the site covers the effectiveness of actions to restore peatland vegetation, shrublands and heathlands, and forests, and evidence for the impacts of habitat restoration on several animal taxa. Work is underway to add the impacts of restoration techniques for grasslands, wetlands and benthic marine habitats, and for more animal taxa. The goal is eventually to cover all interventions that could be used to restore all habitats globally, and to update these regularly to include the latest evidence.

Restoration Evidence makes the evidence for the effects of restoration interventions accessible and digestible, so that 